\title{
Pengaruh Agresivitas Pajak pada Corporate Social Responsibility dengan Profitabilitas sebagai Variabel Moderasi
}

\author{
Ni Wayan Ristiari Jananti ${ }^{1}$ \\ Putu Ery Setiawan ${ }^{2}$ \\ ${ }^{1}$ Fakultas Ekonomi dan Bisnis Universitas Udayana (Unud), Bali, Indonesia \\ email: ristiarijananti@gmail.com/Telp: +62 81238488000 \\ ${ }^{2}$ Fakultas Ekonomi dan Bisnis Universitas Udayana (Unud), Bali, Indonesia
}

\begin{abstract}
ABSTRAK
Suatu perusahaan memiliki tanggung jawab sosial dan lingkungan dalam memperoleh keuntungan. Tinggi rendahnya pengungkapan CSR suatu perusahaan dapat dipengaruhi oleh agresivitas pajak dan profitabilitas. Penelitian ini bertujuan untuk mengetahui pengaruh agresivitas pajak pada CSR serta untuk mengetahui apakah profitabilitas memoderasi pengaruh agresivitas pajak pada CSR. Penelitian ini berfokus pada sektor property dan real estate di Bursa Efek Indonesia. Metode penentuan sampel yang digunakan yaitu non probability sampling dengan teknik purposive sampling. Pengumpulan data menggunakan metode observasi non participant. Teknik analisis data yang digunakan yaitu uji Moderated Regression Analysis. Hasil penelitian menunjukkan bahwa agresivitas pajak berpengaruh positif pada CSR serta profitabilitas mampu memoderasi pengaruh agresivitas pajak pada CSR. Implikasi penelitian, secara teoritis membuktikan teori legitimasi dalam konteks agresivitas pajak dan secara praktis diharapkan memberikan kontribusi positif bagi pihak terkait.
\end{abstract}

Kata kunci: corporate social responsibility, agresivitas pajak, profitabilitas.

\begin{abstract}
A company has a social and environmental responsibility when make a profit. The high level of CSR disclosure of a company can be affected by tax aggressiveness and profitability. This study aims to determine the effect of tax aggressiveness on CSR and to determine whether profitability moderate the influence of tax aggressiveness on CSR.This study focuses on property and real estate sector in Indonesia Stock Exchange. The method of determining the sample used is non probability sampling with purposive sampling technique. Data collection using non participant observation method. Data analysis technique used is test of Moderated Regression Analysis. The results showed that tax aggressiveness has a positive effect on CSR and profitability able to moderate the influence of tax aggressiveness on CSR. The implications of the research, theoretically proving the theory of legitimacy in the context of tax aggressiveness and are practically expected to contribute positively to the parties concerned.

Keywords: corporate social responsibility, tax aggressiveness, profitability.
\end{abstract}

\section{PENDAHULUAN}

Perusahaan dalam menjalankan aktivitas bisnisnya harus memerhatikan berbagai

pihak yang dapat menentukan keberlanjutan perusahaan. Tidak hanya

bertanggung jawab kepada para pemegang saham, perusahaan juga memiliki 
Ni Wayan Ristiari Jananti dan Putu Ery Setiawan. Pengaruh...

tanggung jawab kepada konsumen, karyawan, pemerintah, supplier dan masyarakat. Suatu perusahaan selain dihadapkan pada tanggung jawab dalam memperoleh keuntungan, perusahaan juga diharapkan memerhatikan tanggung jawab sosial dan lingkungannya. Pandangan masyarakat mengenai tindakan yang dilakukan oleh perusahaan kepada para stakeholder termasuk masyarakat dan lingkungan, dapat menentukan kesuksesan dari suatu perusahaan.

Suatu perusahaan mengungkapan kinerja lingkungan, sosial dan ekonomi dalam laporan tahunannya agar komunikasi antara perusahaan dengan publik dan para stakeholder berjalan dengan baik dan efektif. Tanggung jawab sosial atau Corporate Social Responsibility (CSR) merupakan suatu bentuk kepedulian sosial sebuah perusahan kepada masyarakat dan lingkungan sekitarnya. CSR juga diartikan sebagai komitmen perusahaan untuk bertanggung jawab pada dampak operasi perusahaan dalam dimensi sosial, ekonomi serta lingkungan (Heal dan Garnet, 2004).

Perusahaan berharap akan mendapatkan legitimasi sosial dan respon positif dari investor dengan mengungkapkan informasi CSR dalam laporan tahunannya, sehingga kedepannya akan menjadi kekuatan keuangan bagi perusahaan. Menurut Lanis dan Richardson (2012) CSR merupakan salah satu faktor dalam menentukan keberlanjutan hidup perusahaan. CSR merupakan salah satu bentuk tindak lanjut perusahaan dalam Corporate Governance (CG) yang efektif sehingga dapat mewujudkan sustainability melalui implementasi bisnis yang transparan dan dapat dipertanggungjawabkan (Jo dan Harjoto, 2012). 
Menurut Gray, Kouhy dan Lavers (1995) dalam Adelia (2008) pengungkapan kegiatan mengenai CSR hanya berlatar kebutuhan suatu perusahaan untuk membentuk image bahwa dalam pandangan stakeholder perusahaan tersebut telah memiliki kepedulian terhadap lingkungan sosial dan lingkungan hidup. Perusahan berharap memperoleh legitimasi dari masyarakat dan mempertahankan hubungan dalam lingkungan sosial di mana mereka beroperasi. Tanpa adanya legitimasi perusahaan tidak akanmampu bertahan, oleh karena itu perusahaan perlu melakukan pengungkapan terhadap lingkungan di sekitar perusahaan.

Salah satu faktor yang dapat mempengaruhi CSR adalah pajak. Penerimaan negara dari pajak baik itu pajak dalam negeri maupun pajak internasional telah mencapai 80 persen dari total penerimaan dalam Anggaran Pendapatan dan Belanja Negara (APBN) seperti yang ditunjukkan pada Tabel 1. Hal tersebut menunjukkan bahwa pajak merupakan sumber pendapatan terbesar bagi Negara Indonesia untuk menunjang kegiatan perekonomian.

Tabel 1.

Kontribusi Penerimaan Pajak Tahun 2014-2016 (dalam Triliun Rupiah)

\begin{tabular}{cccc}
\hline Tahun & Penerimaan Negara & $\begin{array}{c}\text { Penerimaan Negara dari } \\
\text { Pajak }\end{array}$ & Persentase \\
\hline 2014 & 1.545, & 1.143 & $74 \%$ \\
2015 & 1.496 & 1.236 & $83 \%$ \\
2016 & 1.552 & 1.284 & $83 \%$ \\
\hline
\end{tabular}

Sumber: Data diolah, 2017

Penerimaan negara dari pajak semakin meningkat tiap tahunnya. Penerimaan negara yang bersumber dari pajak sebesar Rp 1.143 triliun rupiah pada tahun 2014 mengalami peningkatan menjadi sebesar Rp 1.284 triliun rupiah 
pada tahun 2016. Meskipun realisasi penerimaan pajak terus meningkat, setiap tahunnya pencapaian target APBN tidak tercapai, seperti yang ditunjukan dalam Tabel 2 berikut.

Tabel 1.

Target dan Realisasi Penerimaan Pajak Tahun 2014-2016 (dalam Triliun Rupiah)

\begin{tabular}{ccc}
\hline \multirow{2}{*}{ Tahun } & \multicolumn{2}{c}{ Penerimaan Pajak } \\
\cline { 2 - 3 } & Target & Realisasi \\
\hline 2014 & 1.246 & 1.143 \\
2015 & 1.489 & 1.236 \\
2016 & 1.539 & 1.284 \\
\hline
\end{tabular}

Sumber: Data diolah, 2017

Menurut Siaran Pers Perpajakan 2017 Center of Indonesia Taxation Analysis (CITA), rasio pajak(tax ratio) Indonesia pada tahun 2014 tergolong rendahdanmasih tertinggal dibanding negara lain.Hal ini ditujukan pada Gambar 1. Rasio pajak memperlihatkan bagaimana pemerintah mampu mengumpulkan pendapatan dari pajak yang dibayarkan masyarakat. Apabila rasio pajak tinggi pada suatu negara, maka pemungutan pajaknya juga semakin baik kinerjanya.

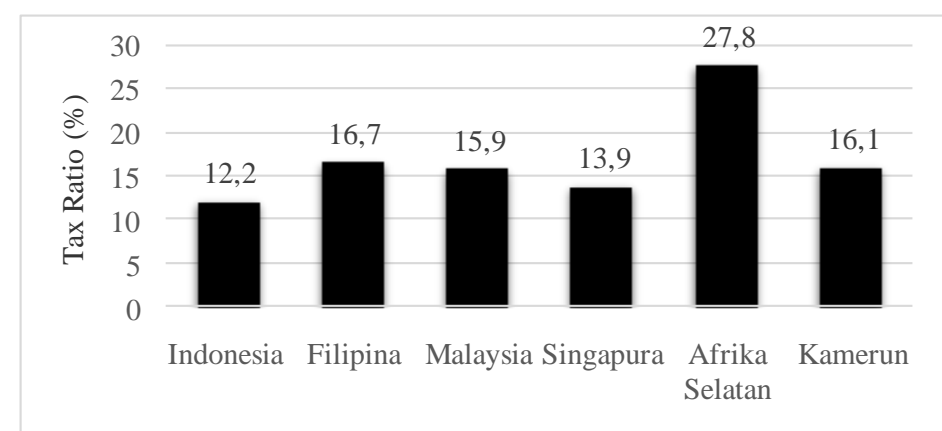

\section{Gambar 1.}

Rasio Pajak (Tax Ratio) Tahun 2014

Sumber: Data diolah, 2017

Tidak terealisasinya target peneriman pajak dan rendahnya tax ratio menunjukkan masih rendahnya kesadaran wajib pajak dalam membayar pajak dan juga mengindikasi adanya tindakan-tindakan yang dilakukan wajib pajak untuk 
menghindarkan pajak. Menurut Lanis dan Richardson (2012) agresivitas pajak merupakan upaya manajemen dalam mengurangi beban pajak yang seharusnya dibayarkan. Sedangkan menurut Hlaing (2012:7), yang dimaksud agresivitas pajak, yaitu suatu kegiatan perencanaan pajak semua perusahaan yang terlibat dalam usaha untuk mengurangi tingkat effective tax rate (ETR) perusahaan. Mekanisme agresivitas pajak bisa dilakukan melalui tax evasion/tax avoidance (Frank et al., 2009).

Menurut Chen et al., (2010) perusahaan bisa agresif dalam perpajakkan guna menurunkaan beban pajakknya. Tindakan agresivitas pajak merupakan tindakan yang dapat merugikan negara dan dipandang sebagai tindakan yang tidak bertanggung jawab sosial. Perusahaan akan melakukan tindakan sosial yang lebih besar guna meminimalisasi dampak tidak baik dari agresivitas pajak, sehingga perusahaan tetap mendapatkan legitimasi. Lanis dan Richradon (2013) mengemukakan, entitas yang terbukti melakukan agresivitas pajak akan mengungkapkan informasi CSR tambahan sebagai wujud tindakan yang sesuai dengan teori legitimasi.

Penelitian tentang pengaruh agresivitas pajak terhadap pengungkapan CSR banyak dilakukan, namun hasil penelitian menunjukkan hasil yang tidak konsisten. Penelitian Octaviana dan Rohman (2014) serta Dewi dan Wirawati (2017) menunjukkan bahwa agresivitas pajak berpengaruh negatif terhadap pengungkapan CSR, sedangkan penelitian Lanis dan Richardson (2013), Utari dan Rohman (2016) serta Aryudanto (2016) menemukan hasil bahwa agresivitas pajak memberikan pengaruh positif pada pengungkapan CSR. Penelitian Nusantari dkk. 
Ni Wayan Ristiari Jananti dan Putu Ery Setiawan. Pengaruh...

(2015) juga menemukan hasil yang berbeda bahwa agresivitas pajak tidak berpengaruh terhadap pengungkapan $C S R$.

Ketidakkonsistenan dari hasil penelitian sebelumnya, mendorong penulis untuk melakukan penelitian kembali mengenai pengaruh agresivitas pajak pada CSR dengan menambahkan variabel moderasi yaitu profitabilitas. Hal ini berkaitan dengan profitabilitas diduga dapat mempengaruhi pengaruh agresivitas pajak pada CSR. Perusahaan dengan profitabilitas tinggi akan melaporkan pajaknya dengan jujur daripada perusahaan yang mempunyai profitabilitas rendah. Hal ini didukung oleh penelitian Noor (2010), Agusti (2014) serta Prasista dan Setiawan (2016). Berbeda hasil dengan penelitian Kurniasih dan Sari (2013), Rinaldi \& Cheisviyanny (2015) serta Andhari dan Sukartha (2017) yang menemukan bahwa profitabilitas memberikan pengaruh positif pada agresifitas pajak. Semakin besar laba yang diperoleh suatu perusahaan, maka semakin agresif pula perusahaan melakukan praktik penghindaran akan kewajiban perpajakannya.

Penelitian ini berfokus pada sektor property dan real estate, karena berdasarkan rencana dan strategi pemeriksaan Direktorat Jendral Pajak 2014, sektor properti menjadi salah satu fokus pemeriksaan sebagai wajib pajak badan. Fenomena lain yang terjadi yaitu adanya penurunan kontribusi 100 wajib pajak besar sektor properti. Menurut Yunirwansyah, Direktur Peraturan Perpajakan II Ditjen Pajak, kontribusi 100 wajib pajak besar di sektor properti menurun paling tajam. Penerimaan dari 100 wajib pajak besar pada sektor properti mencapai Rp 11,03 triliun pada tahun 2015 turun menjadi Rp 6,52 triliun pada tahun 2016 
(Setyowati, 2017). Berdasarkan uraian masalah di atas maka peneliti tertarik untuk mengambil topik penelitian dengan judul "Pengaruh Agresivitas Pajak pada Corporate Social Responsibility dengan Profitabilitas sebagai Variabel Moderasi (Studi Empiris pada Perusahaan Property dan Real Estate yang Terdaftar di Bursa Efek Indonesia Tahun 2014-2016)” .

Tujuan penelitian ini untuk memperoleh bukti empiris mengenai pengaruh agresivitas pajak pada CSR dan mengetahui kemampuan profitabilitas memoderasi pengaruh agresivitas pajak pada CSR. Harapannya penelitian ini dapat memberikan bukti empiris mengenai teori legitimasi dalam menjelaskan hubungan agresivitas pajak dan CSR, disamping juga dapat menambah pengetahuan dan wawasan, serta refrensi dalam meneliti mengenai pengaruh agresivitas pajak pada CSR dengan profitabilitas sebagai variabel pemoderasi. Besar harapan penelitian ini mampu memberikan informasi mengenai pengungkapan corporate social responsibility pada perusahaan property dan real estate dan dapat dijadikan pertimbangan oleh para investor dalam pengambilan keputusan. Hubungan antar variabel dalam penelitian ini ditunjukkan oleh kerangka konseptual pada Gambar 2.

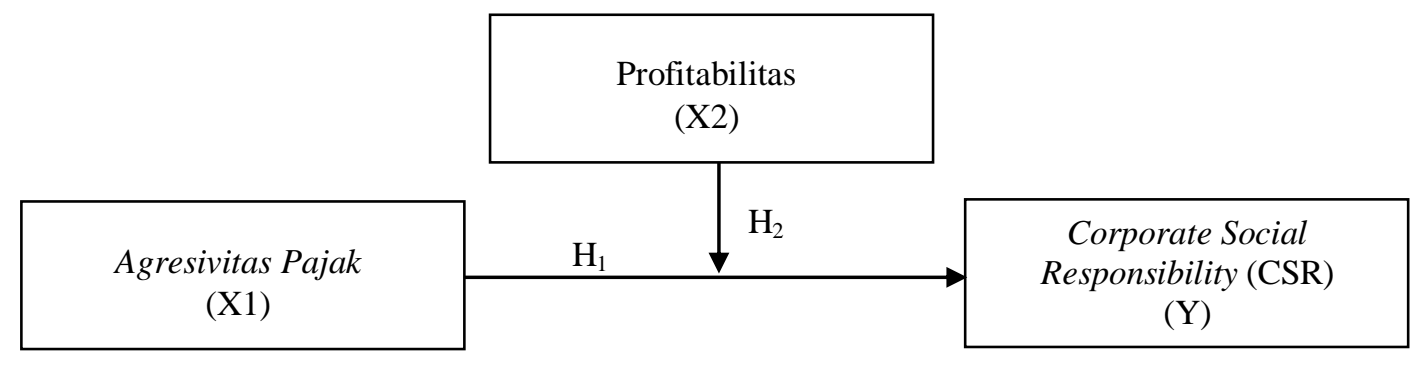

Gambar 2.

Sumber: Data diolah, 2017

Kerangka Konseptual 
Ni Wayan Ristiari Jananti dan Putu Ery Setiawan. Pengaruh...

Teori legitimasi merupakan sistem pengelolaan perusahaan yang berorientasi pada keberpihakan terhadap masyarakat, pemerintah, individu dan kelompok masyarakat (Gray et al., 1996). Legitimasi adalah hal yang penting bagi organisasi karena legitimasi masyarakat terhadap perusahaan menjadi salah satu faktor bagi perkembangan suatu perusahaan. Menurut Dowling dan Pfeffer dalam Muzzaki (2015), untuk mecapai tujuannya, organisasi berusaha untuk menciptakan keselarasan antara nilai-nilai sosial yang ada pada kegiatan organisasi dengan norma-norma yang ada pada lingkungan sosial dimana organisasi tersebut merupakan bagian dalam lingkungan sosial tersebut. Teori legitimasi menyatakan bahwa suatu perusahaan dalam melakukan kegiatan memiliki kontrak sosial dengan masyarakat berdasarkan nilai-nilai justice dan bagaimana perusahaan menanggapi berbagai kelompok kepentingan untuk melegitimasi tindakan perusahaan (Titisari dkk., 2010). Suatu perusahaan dapat kehilangan legitimasinya yang akan mengancam kelangsungan hidup perusahaan, apabila terdapat ketidaksesuaian antara sistem nilai perusahaan dengan sistem nilai masyarakat.

Legitimasi dapat diperoleh apabila terdapat kesesuaian antara keberadaan perusahaan yang tidak mengganggu atau sesuai dengan eksistensi sistem nilai yang ada dalam masyarakat dan lingkungan (Deegan, 2002). Teori legitimasi menganjurkan perusahaan untuk meyakinkan bahwa aktivitas dan kinerjanya dapat diterima oleh masyarakat. Legitimasi memiliki kegunaan dalam mendorong kelangsungan perusahaan (O’Donovan, 2000). 
Tanggung jawab sosial atau CSR merupakan salah satu bentuk interaksi perusahaan dengan masyarakat yang bertujuan untuk memperoleh pandangan yang baik dan dapat diterima oleh masyarakat. Menurut Fontaine (2013), CSR dilakukan bukan hanya untuk kepentingan pelanggan dan investor, namun hal tersebut dilakukan juga untuk kepentingan karyawan, pemasok, pemerintah, dan masyarakat luas. Perusahaan diharapkan dapat mengelola ekonomi, sosial, dan dampak lingkungan dengan melaksanakan CSR tersebut sehingga dapat memaksimalkan manfaat yang didapat dan meminimalkan kerugian.

Kinerja suatu perusahaan yang baik dapat dilihat dari perolehan laba yang tinggi pada tahun berjalan perusahaan tersebut. Laba perusahaan yang tinggi dapat diperoleh dengan cara meminimalisasi beban. Salah satu beban perusahaan adalah beban dalam pembayaran pajak. Pajak bagi perusahaan dianggap sebagai beban yang sebisa mungkin diminimalkan atau bahkan dihilangkan. Berbagai tindakan manajerial dilakukan oleh manajemen untuk mengurangi beban pajak. Agresivitas pajak merupakan semua upaya yang dilakukan oleh pihak manajemen utuk meminimalisir atau menekan beban pajak dari yang seharusnya dibayar oleh perusahaan (Aryudanto, 2016).

Tindakan agresivitas pajak yang dilakukan perusahaan bukan hanya bersumber dari ketidaktaatan perusahaan dengan undang-undang perpajakan, namun tindakan agresivitas pajak dapat pula bertujuan untuk melakukan penghematan dengan memanfaatkan undang-undang sehingga sering kali agresivitas pajak disebut dengan tax sheltering atau tax avoidance (Ridha dan 
Martini, 2014). Agresivitas pajak dapat berwujud apapun selama beban pajak perusahan akan menjadi lebih kecil dari pada beban pajak yang seharusnya.

Salah satu cara untuk mengukur perusahaan yang melakukan agresivitas pajak yaitu dengan mengukur ETR perusahaan. ETR merupakan besaran tarif pajak yang ditanggung oleh perusahaan. ETR dipilih sebagai proksi untuk menghitung agresivitas pajak karena ETR mampu memberikan gambaran menyeluruh mengenai perubahan beban pajak (Maharani dan Suardana, 2015). Nilai ETR yang semakin rendah menunjukkan tingkat agresivitas pajak yang semakin tinggi karena beban pajak penghasilan jauh lebih kecil dari laba sebelum pajak.

Suatu perusahaan akan melakukan berbagai kegiatan sosial yang bertujuan untuk meningkatan kesejahteraan masyarakat sehingga dapat mengurangi dampak negatif yang ditimbulkan dari kegiatan agresivitas pajak. Teori legitimasi menunjukkan suatu perusahaan yang agresif terhadap pajak akan mengungkapkan informasi tambahan yang berkaitan dengan kegiatan CSR di berbagai bidang dalam upaya meringankan perhatian publik dan mencari simpati dari masyarakat (Deegan, 2002). Penelitian Lanis dan Richardson (2013), Utari dan Rohman (2016) serta Aryudanto (2016) menemukan hasil bahwa agresivitas pajak memberikan pengaruh positif pada pengungkapan CSR. Hal ini menunjukkan bahwa perusahaan yang melakukan tindakan agresivitas pajak tinggi akan mengungkapkan laporan tanggung jawab sosial lebih besar dari pada perusahaan yang memiliki agresivitas pajak rendah. Namun penelitian yang dilakukan oleh Octaviana dan Rohman (2014) serta Candra Dewi dan Wirawati (2017) 
menunjukkan bahwa agresivitas pajak berpengaruh negatif dan signifikan terhadap pengungkapan CSR. Berbeda halnya dengan penelitian yang dilakukan oleh Nusantari dkk. (2015) yang menyatakan bahwa agresivitas pajak tidak berpengaruh secara signifikan terhadap pengungkapan CSR. Berdasarkan hal tesebut, maka hipotesis yang diusulkan adalah agresivitas pajak berpengaruh pada corporate social responsibility.

Rasio profitabilitas dapat menunjukkan emampuan perusahaan dalam menghasilkan laba dari kegiatan bisnisnya, sehingga investor dapat mengetahui apakah perusahaan telah mengalokasikan kekayaan dan operasionalnya secara efektif dan efisien dalam menghasilkan laba (Mardiyati dkk., 2012). Menurut Heinze (1976) dalam Heckston dan Milne (1996) profitabilitas merupakan faktor yang membuat manajemen menjadi bebas dan fleksibel untuk mengungkapkan pertanggungjawaban sosial kepada pemegang saham, sehingga semakin tinggi tingkat profitabilitas perusahaan maka semakin besar pengungkapan informasi tanggung jawab sosial perusahaan. Hasil penelitian yang dilakukan oleh Hassan et al., (2006) dan Ebiringa et al., (2013) menyatakan bahwa profitabilitas berpengaruh positif terhadap corporate social responsibility. Hasil yang berbeda ditunjukkan oleh penelitian yang dilakukan oleh Reverte (2009) dan Kurniawansyah (2013) yang menyatakan bahwa profitabilitas tidak berpengaruh terhadap corporate social responsibility.

Menurut Prasista dan Setiawan (2016) perusahaan dengan profitabilitas yang tinggi akan lebih taat membayar pajak. Hal ini karena perusahaan dengan profitabilitas tinggi tidak memiliki kesulitan dalam memenuhi kewajibannya 
Ni Wayan Ristiari Jananti dan Putu Ery Setiawan. Pengaruh...

kepada pemerintah yaitu membayar pajak. Perusahaan yang memiliki profitabilitas tinggi memiliki kesempatan untuk memposisikan diri dalam tax planning yang mengurangi jumlah beban kewajiban perpajakan (Chen et al., 2010). Penelitian Kurniasih (2013), Rinaldi dan Cheisviyanny (2015) serta Andhari dan Sukartha (2017) menyatakan bahwa profitabilitas berpengaruh positif terhadap agresivitas pajak. Semakin besar profitabilitas suatu perusahaan, maka semakin agresif pula perusahaan melakukan praktik penghindaran akan kewajiban perpajakannya. Berdasarkan hal tersebut, maka hipotesis yang diusulkan adalah profitabilitas mampu memoderasi pengaruh agresivitas pajak pada corporate social responsibility.

\section{METODE PENELITIAN}

Penelitian ini menggunakan pendekatan kuantitatif asosiatif dengan tipe kausalitas, yaitu untuk menjelaskan pengaruh variabel independen terhadap variabel dependen (Sugiyono, 2016: 12). Penelitian ini memiliki ruang lingkup pada perusahaan property dan real estate yang terdaftar di Bursa Efek Indonesia (BEI) tahun 2014-2016. Objek penelitian dalam penelitian ini adalah pengungkapan CSR sektor property dan real estate yang terdaftar di BEI tahun 2014-2016 yang diduga dipengaruhi agresivitas pajak dengan profitabilitas sebagai variabel moderasi.

Berdasarkan rumusan masalah serta hipotesis penelitian yang telah dipaparkan, dapat diidentifikasi corporate social responsibility (Y) sebagai variabel terikat, agresivitas pajak (X1) sebagai variabel terikat, dan profitabilitas (X2) sebagai variabel pemoderasi. Variabel pengungkapan CSR dalam penelitian 
ini diukur dengan menggunakan acuan pada indikator Global Reporting Initiative (GRI) versi 4 yang berjumlah 91 item. Pengukuran pengungkapan CSR dilakukan dengan cara mengamati ada tidaknya suatu item informasi yang ditentukan dalam GRI yang diungkapkan dalam annual report. Apabila item informasi tidak ada dalam annual report maka diberi skor "0" dan jika informasi yang ditentukan ada dalam annual report maka diberi skor "1". Skor dari setiap items pengungkapan dijumlahkan dan dibagi dengan total items pengungkapan yang diharapkan untuk setiap indikator sehingga diperoleh skor pengungkapan per indikator untuk setiap perusahaan. Indeks luas pengungkapan CSR (CSRI) dirumuskan sebagai berikut.

$\mathrm{CSRI}=\frac{\sum \mathrm{Xi}_{\mathrm{i}} \mathbf{j}}{\mathrm{nj}}$

Keterangan :

CSRI : Indeks pengungkapan tanggung jawab sosial perusahaan

$\sum \mathrm{X}_{\mathrm{i}, \mathrm{j}}$ : Dummy variable. $(1=\mathrm{jika}$ item i diungkapkan, $0=\mathrm{jika}$ item i tidak diungkapkan)

$\mathrm{n}_{\mathrm{j}} \quad$ : Jumlah item untuk perusahaan $\mathrm{j}, \mathrm{n}_{\mathrm{j}} \leq 91$.

Agresivitas pajak dalam penelitian ini diproyeksikan dengan ETR (Effective Tax rate). Nilai ETR yang rendah menunjukkan tingkat agresivitas pajak yang tinggi. Sebaliknya nilai ETR yang tinggi menunjukkan tingkat agresivitas pajak yang rendah. ETR dihitung dengan rumus sebagai berikut:

$\mathrm{ETR}_{\mathrm{i}, \mathrm{t}}=\frac{\text { Beban pajak i,t }}{\text { Laba sebelum pajak } i_{,}, \mathrm{t}}$

Keterangan:

ETR $_{\mathrm{i}, \mathrm{t}} \quad$ : Effective tax rate perusahaan i pada periode ke- $\mathrm{t}$

Beban pajak $_{\mathrm{i}, \mathrm{t}} \quad$ : Beban pajak perusahaan i pada periode ke-t

Laba sebelum pajak $_{\mathrm{i}, \mathrm{t}}$ : Laba sebelum pajak perusahaan I pada periode ke-t

sedangkan, profitabilitas pada penelitian ini diukur menggunakan Return on Asset (ROA) dengan rumus sebagai berikut: 
$\mathrm{ROA}=\frac{\text { Laba Bersih Setelah Pajak }}{\text { Total Aset }}$

Populasi dalam penelitian ini adalah perusahaan property dan real estate yang terdaftar di Bursa Efek Indonesia dari tahun 2014-2016. Metode penentuan sampel menggunakan metode non probability sampling dengan teknik purposive sampling dengan criteria: (1) Perusahaan property dan real estate yang terdaftar di Bursa Efek Indonesia selama periode 2014-2016, (2) Perusahaan yang mengalami keuntungan berturut-turut dari tahun 2014-2016, (3) Perusahaan menggunakan mata uang rupiah sebagai mata uang pelaporan di laporaran keuangan tahunan, dan (4) Perusahaan yang memiliki data lengkap yang dibutuhkan dalam penelitian meliputi laporan keuangan perusahaan yang telah diaudit dan berakhir pada 31 Desember, data pajak perusahaan serta pengungkapan CSR berturut-turut selama tahun 2014-2016.

Metode pengumpulan data yang digunakan dalam penelitian ini adalah metode observasi nonpartisipan, yaitu teknik pengumpulan data dengan observasi. Berdasarkan sifatnya data yang digunakan pada penelitian ini menggunakan jenis data kuantitatif dan data kualitatif. Data kuantitatif penelitian berupa nama-nama perusahaan sektor property dan real estate di BEI tahun 2014-2016, sedangkan data kuantitatif penelitian berupa laporan keuangan tahunan yang telah diaudit pada perusahaan sektor property dan real estate di BEI tahun 2014-2016. Sumber data dalam penelitian ini adalah sumber data sekunder yang diperoleh dari laporan keuangan perusahaan sektor property dan real estate di Bursa Efek Indonesia tahun 2014-2016 melalui website resmi Bursa Efek Indonesia, yaitu www.idx.co.id dan beberapa website resmi perusahaan yang bersangkutan. Dalam 
penelitian ini dilakukan Uji Statistik Deskriptif, Uji Asumsi Klasik, Uji Koefisien Determinasi, Uji Kelayakan Model dan Uji Hipotesis. Teknik analisis data Moderated Regression Analysis (MRA) digunakan dalam penelitian ini dengan persamaan sebagai berikut:

$Y=\alpha+\beta_{1} X_{1}+\beta_{2} X_{2}+\beta_{3} X_{1} X_{2}+\varepsilon_{1}$

Keterangan:

Y : Corporate Social Responsibility

$\alpha \quad$ : Konstanta

$\beta \quad$ : Koefisien regresi

$\varepsilon \quad:$ Standar error, yaitu tingkat kesalahan penduga dalam penelitian

$\mathrm{X}_{1} \quad$ : Agresivitas Pajak

$\mathrm{X}_{2} \quad$ : Profitabilitas

$\mathrm{X}_{1} \mathrm{X}_{2}$ : Interaksi antara agresivitas pajak dengan profitabilitas

\section{HASIL DAN PEMBAHASAN}

Penelitian ini memperoleh sampel sebanyak 20 perusahaan selama tiga tahun dengan total observasian sebanyak 60 data observasian. Adapun hasil dari analisis sampel dengan menggunakan purposive sampling dapat ditujukan pada Tabel 3 berikut.

Tabel 3.

Hasil Seleksi Sampel dengan Purposive Sampling

\begin{tabular}{|c|c|c|c|}
\hline No. & Keterangan & Jumlah & Akumulasi \\
\hline 1. & $\begin{array}{l}\text { Perusahaan yang terdaftar dalam sektor Property dan Real } \\
\text { Estate di Bursa Efek Indonesia selama tahun pengamatan. }\end{array}$ & (43) & (129) \\
\hline 2. & $\begin{array}{l}\text { Perusahaan Property dan Real Estate yang mengalami } \\
\text { kerugian selama tahun 2014-2016 }\end{array}$ & (8) & (24) \\
\hline 3. & $\begin{array}{l}\text { Perusahaan Property dan Real Estate yang menggunakan } \\
\text { mata uang asing sebagai mata uang pelaporan di laporan } \\
\text { keuangan tahunan. }\end{array}$ & $(0)$ & (0) \\
\hline 4. & $\begin{array}{l}\text { Perusahaan yang tidak memiliki data lengkap yang } \\
\text { dibutuhkan dalam penelitian. }\end{array}$ & (15) & (45) \\
\hline \multicolumn{2}{|c|}{$\begin{array}{l}\text { Jumlah observasian yang memenuhi kriteria selama periode 2012- } \\
2016\end{array}$} & 20 & 60 \\
\hline
\end{tabular}

karakteristik variabel-variabel penelitian, yaitu jumlah sampel, nilai minimum, 
nilai maksimum, nilai rata-rata, dan standar deviasi. Hasil statistik deskriptif penelitian ini dapat dilihat pada Tabel 4 berikut.

\section{Tabel 4.}

Hasil Statistik Deskriptif

\begin{tabular}{lrrrrr}
\hline & $\mathrm{N}$ & \multicolumn{1}{c}{ Minimum } & \multicolumn{1}{c}{ Maximum } & \multicolumn{1}{c}{ Mean } & Std. Deviation \\
\hline CSRI (Y) & 60 & 0,0989 & 0,2527 & 0,1844 & 0,0360 \\
ETR (X $)$ & 60 & 0,0002 & 0,2121 & 0,0424 & 0,0562 \\
ROA (X $)$ & 60 & 0,0068 & 0,1959 & 0.0704 & 0,0435 \\
ETR_ROA $\left(\mathrm{X}_{1 \_} \mathrm{X}_{1}\right)$ & 60 & 0,0000 & 0,0093 & 0,0019 & 0,0022 \\
\hline
\end{tabular}

Sumber: Data diolah, 2017

Variabel CSRI yang menggambarkan corporate social responsibility mempunyai nilai minimum 0,0989 dimiliki oleh PT Metropolitan Kentjana Tbk. pada tahun 2014 dan nilai maksimum sebesar 0,2527 dimiliki oleh PT Bumi Serpong Damai Tbk. pada tahun 2015 dan 2016. Nilai rata-rata variabel CSR sebesar 0,1844 menunjukkan bahwa rata-rata perusahaan sampel telah mengungkapkan 18,44\% artinya perusahaan mengungkapkan 17 dari 91 item pengungkapan berdasarkan Global Reporting Initiative Generation 4. Nilai standar deviasi CSR sebesar 0,0360.

Variabel ETR yang menggambarkan agresivitas pajak memiliki nilai minimum sebesar 0,0002 dimiliki oleh PT Metropolitan Kentjana Tbk. pada tahun 2014 dan nilai maksimum senilai 0,2121 dimiliki oleh PT Lippo Karawaci Tbk. pada tahun 2016. Nilai rata-rata ETR sebesar 0,0424 memiliki arti bahwa beban pajak dari laba sebelum pajak perusahaan adalah 4,24\%. Nilai standar deviasi agresivitas pajak sebesar 0,0562. Variabel ROA yang menggambarkan profitabilitas mempunyai nilai minimum 0,0068 dimiliki oleh PT Bekasi Asri Pemula Tbk. pada tahun 2015 dan nilai maksimum sebesar 0,1959 dimiliki oleh PT Lippo Cikarang Tbk. pada tahun 2014. Nilai rata-rata profitabilitas sebesar 
0,0704 memiliki arti bahwa rata-rata perusahaan sampel dapat memperoleh laba bersih sebesar $7,04 \%$ dari total aset yang dimiliki perusahaan. Standar deviasi profitabilitas sebesar 0,0435. Variabel Interaksi agresivitas pajak dan profitabilitas memiliki nilai minimum sebesar 0,000 dan nilai maksimum sebesar 0,0093. Nilai rata-rata variabel interaksi sebesar 0,0019 dan standar deviasi sebesar 0,0022.

Uji asumsi klasik dilakukan selanjutnya agar data yang digunakan dalam pengujian hipotesis, bebas dari asumsi klasik sehingga suatu penelitian mendapatkan model yang layak diteliti. Uji asumsi klasik penelitian ini terdiri dari uji normalitas, uji autokorelasi, dan uji heteroskedastisitas. Data dapat dikatakan berdistribusi normal apabila nilai Asymp. Sig (2-tailed) lebih besar dari level of significant yang digunakan, yaitu 5\% $(0,05)$. Berdasarkan perhitungan didapat nilai Asymp. Sig. (2-tailed) sebesar 0,887 lebih besar dari tingkat signifikansi 0,05, yang berarti data telah berdistribusi normal. Kemudian dilakukan uji autokorelasi dengan tujuan menguji apakah dalam model regresi linier ada korelasi antara pengganggu pada periode $\mathrm{t}$ dengan kesalahan pengganggu pada periode sebelmnya (t-1). Model regresi tidak terdapat autokorelasi apabila nilai $\mathrm{dU}<\mathrm{d}<$ (4-dU). Hasil uji autokorelasi ditujukan pada Tabel 5 berikut.

Tabel 5.

Hasil Uji Autokorelasi

\begin{tabular}{cccccc}
\hline Model & R & R Square & $\begin{array}{c}\text { Adjusted R } \\
\text { Square }\end{array}$ & $\begin{array}{c}\text { Std. Error of the } \\
\text { Estimate }\end{array}$ & Durbin-Watson \\
\hline 1 & 0,454 & 0,206 & 0,163 & 0,0330 & 1,980 \\
\hline
\end{tabular}

Sumber: Data diolah, 2017 
Ni Wayan Ristiari Jananti dan Putu Ery Setiawan. Pengaruh...

Berdasarkan Tabel 5 dapat dilihat bahwa nilai uji Durbin Watson sebesar 1,980. Nilai dU untuk jumlah sampel 60 dengan 3 variabel bebas (k) serta level of significant 5\% (0,05) adalah 1,689. Maka nilai 4-dU adalah 2,311, sehingga hasil uji autokolerasinya adalah $\mathrm{dU}<\mathrm{d}<(4-\mathrm{dU})$, yaitu $1,689<1,980<2,311$. Hal ini berarti koefisien regresi, bebas dari gangguan autokolerasi.

Uji heteroskedastisitas pada penelitian ini dilakukan melalui Uji Glejser dengan meregresikan nilai absolute residual sebagai variabel terikat dengan variabel bebas. Jika variabel bebas yang dianalisis tidak mempunyai pengaruh yang signifikan terhadap absolute residual, berarti model regresi yang dianalisis tidak mengandung gejala heteroskedastisitas. Hasil uji heteroskedastisitas ditunjukkan pada Tabel 6 berikut.

Tabel 6.

Hasil Uji Heteroskedastisitas

\begin{tabular}{clcl}
\hline No. & \multicolumn{1}{c}{ Variabel } & Sig. & Keterangan \\
\hline 1 & Agresivitas Pajak & 0,828 & Bebas Heteroskedastisitas \\
2 & Profitabilitas & 0,905 & Bebas Heteroskedastisitas \\
3 & Interaksi & 0,917 & Bebas Heteroskedastisitas \\
\hline
\end{tabular}
Sumber: Data diolah, 2017

Tabel 6 memperlihatkan bahwa nilai signifikansi seluruh variabel bebas pada penelitian ini lebih besar dari 0,05 yang berarti data penelitian ini bebas dari heteroskedastisitas.

Moderated Regression Analysis (MRA) dilakukan guna mengetahui pengaruh variabel independen terhadap variabel dependennya dan kemampuan variabel pemoderasi dalam memoderasi pengaruh variabel independen terhadap variabel dependennya. Hasil uji MRA ditujukan pada Tabel 7 berikut. 
Tabel 7.

Hasil Uji Moderated Regression Analysis

\begin{tabular}{|c|c|c|c|c|c|c|}
\hline & \multirow[t]{2}{*}{ Model } & \multicolumn{2}{|c|}{ Unstandardized Coefficients } & \multirow{2}{*}{$\begin{array}{c}\begin{array}{c}\text { Standardized } \\
\text { Coefficients }\end{array} \\
\text { Beta } \\
\end{array}$} & \multirow[t]{2}{*}{$\overline{\mathbf{t}}$} & \multirow[t]{2}{*}{ Sig. } \\
\hline & & $\mathbf{B}$ & Std. Error & & & \\
\hline \multirow{4}{*}{1} & (Constant) & 0,209 & 0,011 & & 18,516 & 0,000 \\
\hline & $\operatorname{ETR}\left(\mathrm{X}_{1}\right)$ & $-0,615$ & 0,182 & $-0,959$ & $-3,378$ & 0,001 \\
\hline & $\operatorname{ROA}\left(\mathrm{X}_{2}\right)$ & $-0,221$ & 0,125 & $-0,267$ & $-1,769$ & 0,082 \\
\hline & $\begin{array}{l}\text { ETR_ROA } \\
\left(\mathrm{X}_{1} \mathrm{X}_{2}\right)\end{array}$ & 9,268 & 4,215 & 0,564 & 2,199 & 0,032 \\
\hline \multicolumn{2}{|c|}{ Adjusted R Square } & & & & & 0,163 \\
\hline \multicolumn{2}{|c|}{$\mathrm{F}$} & & & & & 4,837 \\
\hline \multicolumn{2}{|c|}{ F Sig } & & & & & 0,005 \\
\hline
\end{tabular}

Sumber: Data diolah, 2017

Merujuk pada Tabel 7 diatas, maka persamaan MRA pada penelitian ini adalah berikut.

$\mathrm{CSR}=0,209-0,615 \mathrm{X}_{1}-0,221 \mathrm{X}_{2}+9,268 \mathrm{X}_{1} \mathrm{X}_{2}+\mathrm{e}$

Interpretasi persamaan MRA tersebut sebagai berikut. Konstanta $(\alpha)$ senilai 0,209 memiliki arti apabila seluruh variabel independen sama dengan nol, maka CSR (Y) yang diprediksi dengan CSRI meningkat sebesar 0,209. Koefisien regresi $\left(\beta_{1}\right)$ dari agresivitas pajak $\left(\mathrm{X}_{1}\right)$ senilai $-0,615$ berarti apabila nilai agresivitas pajak yang diprediksi dengan ETR naik sebesar 1 satuan, maka CSR (Y) yang diprediksi dengan CSRI mengalami penurunan sebesar 0,615 satuan, dengan asumsi variabel independen lainnya konstan. Koefisien regresi $\left(\beta_{2}\right)$ profitabilitas $\left(\mathrm{X}_{2}\right)$ senilai $-0,221$ berarti apabila nilai profitabilitas yang diprediksi dengan ROA meningkat sebesar 1 satuan maka maka CSR (Y) yang diprediksi dengan CSRI menurun sebesar 0,221 satuan, dengan asumsi variabel independen lainnya konstan. Nilai koefisien regresi interaksi $\left(\beta_{3}\right)$ dari agresivitas pajak dan profitabilitas $\left(\mathrm{X}_{1} \mathrm{X}_{2}\right)$ sebesar 9,268 memiliki arti bahwa ketika nilai interaksi meningkat sebesar 1 satuan, maka CSR (Y) yang diproksikan dengan CSRI meningkat seb sebesar 9,268 satuan dengan asumsi variabel independen lainnya 
Ni Wayan Ristiari Jananti dan Putu Ery Setiawan. Pengaruh...

konstan. Nilai koefisien regresi interaksi $\left(\beta_{3}\right)$ dari agresivitas pajak dan profitabilitas $\left(\mathrm{X}_{1} \mathrm{X}_{2}\right)$ sebesar 9,268 memiliki arti bahwa ketika nilai interaksi meningkat sebesar 1 satuan, maka CSR (Y) yang diproksikan dengan CSRI menigkat sebesar 9,268 satuan dengan asumsi variabel independen lainnya konstan.

Untuk uji koefisien determinasi, pada Tabel 7 menunjukkan nilai koefisien determinasi sebesar 0,163 yang berarti $16,3 \%$ variasi corporate social responsibility dapat dijelaskan oleh variasi dari agresivitas pajak dan interaksi antara agresivitas pajak dan profitabilitas, sedangkan sebesar 83,7\% dapat dijelaskan oleh variabel-variabel lain di luar model penelitian. Selanjutnya untuk uji kelayakan model, pada Tabel 7 signifikansi $\mathrm{F}$ sebesar 0,005 lebih kecil dari 0,05 maka dapat disimpulkan bahwa model penelitian dapat dikatakan layak untuk diteliti dan dapat dilanjutkan dengan pembuktian hipotesis.

Uji hipotesis (uji t) berdasarkan Tabel 7, dapat diartikan sebagai berikut. Hipotesis pertama $\left(\mathrm{H}_{1}\right)$ penelitian ini mengemukakan bahwa agresivitas pajak berpengaruh pada corporate social responsibility. Mengacu pada hasil uji statistik t pada Tabel 7 dapat dilihat nilai signifikansi variabel agresivitas pajak $\left(\mathrm{X}_{1}\right)$ yang diproksikan dengan ETR adalah 0,001 $<0,05$ maka $\mathrm{H}_{1}$ diterima. Hal ini berarti agresivitas pajak berpengaruh terhadap corporate social responsibility. Koefisien regresi yang negatif menunjukkan ETR sebagai proksi agresivitas pajak berpengaruh negatif pada corporate social responsibility. ETR yang rendah menunjukkan tingkat agresivitas pajak yang tinggi, sehingga hasil penelitian ini menunjukkan bahwa semakin tinggi agresivitas pajak maka pengungkapan 
corporate social responsibility akan meningkat. Suatu perusahaan yang memiliki tingkat agresivitas pajak tinggi akan mengungkapkan informasi corporate social reponsibility lebih besar untuk memperoleh legitimasi dari masyarakat.

Tindakan agresivitas pajak merupakan tindakan yang tidak sesuai dengan harapan masyarakat dan memiliki dampak negatif terhadap masyarakat. Pandangan negatif masyarakat terhadap perusahaan, berpotensi terhadap hilangnya legitimasi perusahaan yang akan mengancam kelangsungan hidup perusahaan. Hal ini mendorong perusahaan untuk mengungkapkan tanggung jawab sosialnya lebih luas sehingga dapat mengurangi dampak negatif yang ditimbulkan dari kegiatan agresivitas pajak.

Hasil penelitian ini didukung oleh penelitian Lanis dan Richardson (2013), Plorensia dan Hardiningsih (2015), Utari dan Rohman (2016) serta Aryudanto (2016). Hasil penelitian juga membuktikan teori legitimasi dalam konteks agresivitas pajak, yang menyatakan perusahaan yang melakukan tindakan agresivitas pajak tinggi akan mengungkapkan laporan tanggung jawab sosial lebih besar dari pada perusahaan yang memiliki agresivitas pajak rendah.

Hipotesis kedua $\left(\mathrm{H}_{2}\right)$ penelitian ini mengemukakan bahwa profitabilitas mampu memoderasi hubungan agresivitas pajak pada corporate social responsibility. Mengacu pada hasil uji statistik pada Tabel 7 menunjukkan bahwa nilai interaksi memiliki tingkat signifikansi sebesar $0,032<0,05$ maka $\mathrm{H}_{2}$ diterima. Hal ini berarti profitabilitas mampu memoderasi hubungan agresivitas pajak pada corporate social responsibility. Tabel 7 menunjukkan nilai $\beta_{2}$ tidak signifikan dan $\beta_{3}$ signifikan, maka dapat disimpulkan bahwa profitabilitas 
Ni Wayan Ristiari Jananti dan Putu Ery Setiawan. Pengaruh...

merupakan variabel moderasi asli (pure moderator). Nilai koefisien regresi interaksi antara agresivitas pajak dan profitabilitas $\left(X_{1} X_{2}\right)$ sebesar 9,268, menunjukkan bahwa profitabilitas memperkuat pengaruh agresivitas pajak pada corporate social responsibility. Hal ini berarti jika terjadi peningkatan profitabilitas maka akan memperkuat pengaruh agresivitas pajak pada corporate social responsibility.

Profitabilitas suatu perusahaan dapat menjadi faktor yang dipertimbangkan dalam melakukan agresivitas pajak. Semakin tinggi tingkat profitabilitas suatu perusahaan maka laba yang dihasilkan perusahaan akan semakin besar. Semakin besar laba yang diperoleh perusahaan akan meningkatkan pajak yang dibayarkan perusahaan. Hal ini dapat menjadi motivasi bagi perusahaan untuk melakukan tindakan yang dapat mengurangi beban pajaknya sehingga menyebabkan perusahaan tersebut agresif terhadap pajak. Hasil ini sejalan dengan penelitian Kurniasih (2013), Rinaldi (2015) serta Andhari dan Sukartha (2017) yang menyatakan bahwa profitabilitas berpengaruh positif terhadap agresifitas pajak. Semakin tinggi profitabilitas maka semakin agresif perusahaan terhadap pajaknya. Sehingga dapat disimpulkan bahwa perusahaan yang memiliki tingkat agresivitas pajak tinggi akan mengungkapkan informasi corporate social reponsibility lebih besar pada saat profitabilitas perusahaan meningkat.

\section{SIMPULAN}

Berdasarkan hasil analisis dan pembahasan yang telah dilakukan sebelumnya, maka dapat ditarik simpulan sebagai berikut: (1) Agresivitas pajak berpengaruh positif pada corporate social responsibility, artinya semakin tinggi tingkat 
agresifitas pajak perusahaan maka tingkat pengungkapan corporate social responsibility akan semakin tinggi, (2) Profitabilitas mampu memoderasi pengaruh agresivitas pajak pada corporate social responsibility. Profitabilitas memperkuat pengaruh agresivitas pajak pada corporate social responsibility, artinya peningkatan profitabilitas akan memperkuat pengaruh agresivitas pajak pada corporate social responsibility.

Saran yang dapat disampaikan dalam penelitian ini yaitu: (1) Bagi perusahaan, khususnya perusahaan property dan real estate diharapkan mampu meningkatkan pelaksanaan dan pengungkapkan corporate sosial responsibility, karena data penelitian menunjukkan pengungkapan corporate social responsibility perusahaan property dan real estate masih rendah, (2) Bagi investor, sebaiknya tidak hanya memperhatikan pengungkapan corporate social responsibility tetapi menganalisa effective tax rate yang dapat menunjukkan agresivitas pajak karena berdasarkan penelitian ini pengungkapan corporate social responsibility terbukti sebagai strategi perusahaan untuk memperoleh legitimasi dari masyarakat atas tindakan agresivitas pajak yang dilakukan perusahaan.

\section{REFERENSI}

Adelia, H. 2008. Analisis Faktor-Faktor yang Mempengaruhi Kelengkapan Pngungkapan Sosial dalam Laporan Tahunan Perusahaan (Studi Pada Perusahaan High Profile Yang Terdaftar di BEI). Skripsi. Sarjana Jurusan Akuntansi Fakultas Ekonomi Universitas Brawijaya Malang.

Agusti, Wirna Yola. 2014. Pengaruh Profitabilitas, Leverage, Corporate Governance Terhadap Tax Avoidance. E-Jurnal Fakultas Ekonomi Universitas Negeri Padang, 2(3).

Andhari, Putu Ayu Seri dan Sukartha, I Made. 2017. Pengaruh Pengungkapan Corporate Social Responsibility, Profitabilitas, Inventory Intensity, Capital 
Intensity dan Leverage pad Agresivitas Pajak. E-Jurnal Akuntansi Universitas Udayana, 18(3), hal. 2115-2141.

Aryudanto, Indra. 2016. Analisis Pengaruh Agresivitas Pajak Terhadap Pengungkapan Corporate Social Responsibility. Skripsi. Semarang: Universitas Diponegoro.

Center for Indonesia Taxation Analysis. 2017. Siaran Pers Perpajakan 2017: Menjaga Momentum, Mencari Peluang. https://www.cita.or.id/opini/ siaran-pers/siaran-pers-cita-perpajakan. 2017. Diakses pada 17 Oktober 2017.

Chen, Shuping, Xia Chen, Qiang Cheng dan Terry Shevlin. 2010. Are Family Firms More Tax Aggressive Than Non-family Firms. Journal of Financial Economics, 91(1), hal. 41-61.

Deegan, C. 2002. Introduction: The Legitimising Effect of Social and Environmental Disclosure - A Theoritical Foundation. Accounting, Auditing, and Accountability Journal, 5(3), hal. 282-311.

Dewi, Ida Ayu Agung Wahyuning Candra dan Ni Gusti Putu Wirawati. Pengaruh Agresivitas Pajak pada Corporate Social Responsiility dengan Likuiditas Sebagai Variabel Pemoderasi. E-Jurnal Akuntansi Universotas Udayana, 19(3), hal. 1943-1969.

Fontaine, Michael. 2013. Corporate Social Responsibility and Sustainability: The New Bottom Line. International Journal of Business and Social, 4 (4), hal. 110-119.

Frank, M.M., Lynch, L.J. dan Rego, S.O. 2009. Tax Reporting Aggressiveness and Its Relation to Aggressive Financial Reporting. The Accounting Review, 84(2), hal. 467-496.

Gray, R.H., Owen, D.L. dan Adams, C.A. 1996. Accounting and Accountability: Changes and Challenges in Corporate Social and Environmental Reporting, Europe: Prentice Hall.

Hassan, O., Giorgioni, G. dan Romilly, Peter. 2006. The Extent of Financial Disclosure and Its Determinants in an Emerging Capital Market: The Case of Egypt. International Journal of Accounting, Auditing and Performance Evaluation, 3(1), hal. 41-67.

Heal, Geoffrey, dan Garnet, Paul. 2004. Corporate Social Responsibility, an Economic and Financial Framework. Columbia Business School.

Hlaing, K.P. 2012. Organizational Architecture of Multinationals and Tax Aggressiveness. Canada: University of Waterloo. 
Jo, Hoje dan Maretno A. Harjoto. 2012. The Causal Effect of Corporate Governance on Corporate Social Responsibility. Journal of Business Ethics, 106 (1), hal. 53-72.

Kurniasih, T. dan Sari, Maria M. 2013. Pengaruh Profitabilitas, Leverage, Corporate Governance, Ukuran Perusahaan, dan Kompensasi Rugi Fiskal pada Tax Avoidance. Buletin Studi Ekonomi, 18, hal. 58 - 66.

Kurniawansyah,D. 2013. Analisis Hubungan Financial Performance dan Corporate Social Responsibility Perusahaan Perbankan yang Terdaftar di BEI. Skripsi. Semarang: Program Sarjana Fakultas Ekonomika dan Bisnis Universitas Diponogoro.

Lanis, R., dan G. Richardson. 2012. Corporate Social Responsibility and Tax Aggresiveness: An Empirical Analysis. J. Account. Journal of Accounting and Public Policy, 31(1), hal. 86-108.

Lanis, R., dan G. Richardson. 2013. Corporate Social Responsibility and Tax Aggressiveness: A Test of Legitimacy Theory. Accounting Auditing and Accountability Journal, 26 (1), hal. 75-100.

Maharani, I Gusti Ayu Cahya dan Ketut Alit Suardana. 2014. Pengaruh Corporate Governance, Profitabilitas, dan Karakter Eksekutif Pada Tax Avoidance Perusahaan Manufaktur. E-jurnal Akuntansi Universitas Udayana, 9(2), hal. 525-539.

Mardiyati, Umi, Gatot Nazir Ahmad dan Ria Putri. 2012. Pengaruh Kebijakan Dividen, Kebijakan Hutang dan Profitabilitas Terhadap Nilai Perusahaan Manufaktur yang Terdaftar di Bursa Efek Indonesia (BEI) Periode 20052010. Jurnal Riset Manajemen Sains Indonesia (JRMSI), 3(1).

Nusantari, Nanda Inggar, Nuzula, Nila Firdausi dan Darno, Agung. 2015. Pengaruh Agresivitas Pajak Terhadap Pengungkapan Corporate Social Responsibility (CSR). Jurnal Akuntansi Bisnis, 5(2); hal. 1-9.

Noor, Rohaya Md., Nur Syazwani M. Fadzillah dan Nor Azam Matsuki. 2010. Corporate Tax Planning: A Study on Corporate Effective Tax Rates of Malaysian Listed Companies. International Journal of Trade, Economics and Finance, 1 (2): hal. 189-193.

Octaviana, N. Elma., dan A. Rohman. 2014. Pengaruh Agresivitas Pajak tehadap Corporate Social Responsibility: Untuk Menguji Teori Legitimasi. Diponegoro Journal of Accounting, 3(2): hal.1-12.

O'Donovan. 2000. Environmental Disclosure in the Annual Reports: Extending the Applicability and Predictive Power of Legitimacy Theory. Accounting, Auditing and Accountability Journal, 15 (3), hal. 344-371. 
Plorensia, Winda dan Pancawati Hardiningsih. 2015. Pengaruh Agresivitas Pajak dan Media Explosure Terhadap Corporate Social Responsibility. Dinamika Akuntansi, Keuangan dan Perbankan, 4(2), hal. 136-151.

Prasista, Putu Meita dan Ery Setiawan. 2016. Pengaruh Profitabilitas dan Pengungkapan Corporate Social Responsibility Terhadap Agresivitas Pajak Penghasilan Wajib Pajak Badan. E-Jurnal Akuntansi Universitas Udayana, 17(3), hal. 2120-2144.

Reverte, C. 2009. Determinants of Corporate Social Responsibility Disclosure Ratings by Spanish Listed Firms. Journal of Business Etchics, 88(2), hal. 351-366.

Ridha, Muhamad dan Martini, Dwi. 2014. Analisis terhadap Agresivitas pajak, Agresivitas Pelaporan Keuangan, dan Tata Kelola Perusahaan di Indonesia. Simposium Nasional Akuntansi XVII Mataran, Lombok. 24-27 September 2014.

Rinaldi, dan Cheisviyanny, Charoline. 2015. Pengaruh Profitabilitas, Ukuran Perusahaan dan Kompensasi Rugi Fiskal terhadap Tax Avoidance (Studi Empiris pada Perusahaan Manufaktur Yang terdaftar di BEI Tahun 20102013). SNEMA-2015 Padang Indonesia.

Setyowati, Desi. 2017. Ditjen Pajak: Kontribusi 100 Wajib Pajak Besar Sektor Property Anjlok. http://www.katadata.co.id. Diakses pada 17 Oktober 2017.

Sugiyono. 2016. Metode Penelitian Pendidikan (Pendekatan Kuantitatif, Kualitatif, dan $R \& D)$. Bandung: Alfabeta

Titisari, Hendra K., E. Suwardi, dan D. Setiawan. 2010. Corporate Social Responsibility (CSR) dan Kinerja Perusahaan. Simposium Nasional Akuntansi XIII, Purwokerto.

Utari, Intan Ayu dan Abdul Rohman. 2015. Pengaruh Agresivitas Pajak terhadap Corporate Social Responsibility: Untuk Menguji Teori Legitimasi (Studi Empiris Pada Perusahaan Manufaktur yang Terdaftar di Bursa Efek Indonesia Tahun 2011-2013). Diponogoro Journal of Accounting, 4(1), hal. 1-13. 